\title{
Mermer Üretim İşletmelerinin Sosyal Sorumluluk Kavramı Kapsamında Çevre ve Çevre Muhasebesine Yaklaşımları: Bir Araştırma
}

Ali APALI *

\section{ÖZET}

Çevre muhasebesi, işletme ve çevre etkileşimi sonucunda çevrede ortaya çıkan ya da olası etkilerin maliyetleri ile ilgili bütün işlemleri konu edinmiştir. Işletmelerin çevre ve çevre muhasebesine karşı yaklaşımları çalışmada konu olarak belirlenmiştir. Belirlenen konu çerçevesinde, mermer üretim işletmelerinin çevre muhasebesine karşı farkındalıklarında, sosyal sorumluluk kavramı çerçevesinde çevre koruma bilincinin etkisinin olup olmadı̆̆ııın araştırılması çalışmanın amacını oluşturmuştur. Bu amaca, Burdur ili Bucak ilçesindeki mermer üretim işletmeleri örnekleminde birinci kısmı tanımlayıcı sorular ikinci kısmı ise yargılardan oluşan anket veri toplama yöntemi ile sonuca ulaşılmıştır. 56 adet mermer üretim işletmesine uygulanan anket ile elde edilen veriler, SPSS 20.0 versiyonu ile analiz edilmiştir. Çalışmada çevre muhasebesi ve çevre bilinci ile ilgili 10 adet hipotez geliştirilmiştir. Bu hipotezler regresyon yöntemi ile test edilmiş ve araştırma sonucunda hipotezlerin tamamı kabul edilmiştir.

Anahtar Kelimeler: Çevre, Çevre Muhasebesi, Mermer Üretim İşletmeleri, Burdur-Bucak.

JEL Siniflandırması: M41, M49.

\section{Environment and Environmental Accounting Approaches of Marble Production} Companies within the Scope of Social Responsibility Practices: A Research

\section{ABSTRACT}

Environmental accounting covers all topics related to the costs of the present or potential environmental effects that might come out as a result of the interaction between the company and environment. Environment and environmental accounting approaches of companies constitute the subject of this research. Within the framework of the specified subject, this study aims to find out whether the consciousness about environmental protection has any effect in environmental accounting awareness of marble production companies within the scope of social responsibility practices. In order to achieve this aim, the survey method was used to a sample group of marble production companies in Burdur province, Bucak district. The first part of the study consisted of descriptive questions and the second part consisted of judgments. The data obtained from 56 marble production companies were analyzed with the SPSS 20.0 model. 10 hypotheses about environmental accounting and environmental awareness were developed in the study. These hypotheses were tested with the regression method and all the hypotheses were accepted at the end.

Keywords: Environment, Environmental Accounting, Marble Production Companies, BurdurBucak.

Jel Classification: M41, M49.

\footnotetext{
*Yrd.Doç.Dr. Ali Apalı, Mehmet Akif Ersoy Üniversitesi, Zeliha Tolunay Uygulamalı Teknoloji ve İşletmecilik Yüksekokulu, aliapali.35@gmail.com
} 


\section{GİRiş}

İşletmelerin temel amacı, iç ve diş paydaşların menfaatlerini ön plana çıkarmaktır. İşletme paydaşları hissedarlar, yöneticiler, çalışanlar, mal ya da hizmet tedarikçileri, finansörler, tüketiciler, sendikalar, devlet, sendikalar, aktivist gruplar, medya vb. şeklinde sıralanmaktadır. Paydaşlar işletme ile doğrudan etkileşim halinde olan tarafların yanı sıra dolaylı etkileşim içinde olan tarafları da kapsamaktadır. Dolaylı ya da dolaysız bütün taraflar, işletme-çevre etkileşimini takip etme eğilimi içerisinde olacaklardır. Bu duruma ilişkin çevreye karşı duyarsız bir işletmenin faaliyetlerinin, bazen halk veya tüketici paydaşları tarafindan talep edilmemesi yaklaşımı örnek olarak verilebilir. İşletme paydaşlarından çevre, özellikle modern işletme amaçları içerisinde sayılmaktadır. Bu durum çevre ile ilgili konuları, işletmelerin özen göstermesi gereken konular arasında gösterilmesine neden olmaktadır. İşletmeler açısından çevreye duyarlı faaliyetlerin bulunması, işletmelerin sorumlu davranma yaklaşımı çerçevesinde değerlendirilmektedir. İşletmelerin çevresine karşı sorumlu faaliyetler içerisinde olması, aslında işletmelerin sosyal sorumluluk kavramına uygun olarak faaliyette bulunduğunun göstergesidir.

Üretim işletmeleri çevre ile doğrudan etkileşim halindeki işletmelerdir. Özellikle ilk maddesini doğrudan doğadan karşılayan mermer üretim işletmeleri çevre ile daha yakından ilişkili olan işletmelerdir. Mermer üretim işletmelerinin üretimlerini gerçekleştirirken çevreinsan-toplum çerçevesinde sosyal sorumluluk temelinde çevre ve çevre muhasebesine bakış açılarını tespit etmeye yönelik hazırlanan çalışmada önce sosyal sorumluluk-çevre ve çevre muhasebesi kavramlarının ilişkileri tartışıldıktan sonra, çevre ve çevre muhasebesi ile ilgili çalışmaların literatür taraması yapılarak bazıları devam eden başlıkta aktarılmıştır. En son başlıkta Burdur İli Bucak ilçesinde faaliyet gösteren mermer işletmeleri üzerine yapılan araştırmaya yer verilmiştir.

\section{KAVRAMSAL ÇERÇEVE}

Sosyal sorumluluk kavramı, kişi ve kurumların değil, tüm toplumun çıkarlarının ön planda tutulması anlamında kullanılmaktadır. Özellikle son yıllarda çevreci grupların ve toplumun duyarlılıkları ile çevre kavramı işletmelerin sosyal sorumluluk kavramı ile birlikte anılır olmuştur. Çevre, işletmelerin toplumsal sorumluluğun bir parçası değil aynı zamanda işletmelerin geleceğini de ilgilendiren konuların başında yer almaktadır.

Muhasebede sosyal sorumluluk anlayışı, hukuki sorumluluğun sınırlarını aşan bir kavram olup, işletmelerin faaliyetlerinin toplum üzerindeki zararlı etkilerini önlemeye yönelik bir araç niteliğindedir (Marşap, 1999: 178). Bundan dolayı muhasebe, işletmelerin finansal raporlarını hazırlamasının yanında toplumu ilgilendiren konularda da rol üstlenmektedir.

Çevre kavramı ise insan başta olmak üzere canlı-cansız varlıkların belirli bir sürede dolaylı ya da dolaysız bir etkide bulunabilecek fiziksel, kimyasal, biyolojik ve toplumsal etkilerinin toplamı olarak tanımlanmaktadır (Keleş,2002: 28). Bu kavram, başta insanlar olmak üzere bütün canlıların ve cansızların birbirlerini karş1lıklı olarak etkiledikleri ortamdır. Çevre ile ilgili birçok tanım yapmak olasıdır. Ancak tanımdan öte çevre kavramında bulunan iki yönlü ilişkinin varlığı söz konusudur. Gerek canlı varlıklar gerekse cansız olan varlıklar hem etkileşimde olan taraftan etkilenmekte hem de etkileşimde olunan tarafı etkilemektedir. Çevre kavramında asıl olan insandır. İnsanların çevre unsurunun merkezinde 
olduğu ve onu dolaylı ya da dolaysız olarak şekillendirmektedir. İnsanın giderek çevre üzerindeki sert müdahaleleri işletmeler açısından yeni bir kavram olan çevre muhasebesi kavramını ortaya çıkarmaktadır.

Sosyal sorumluluk kavramı sonucunda sosyal sorumluluk muhasebesi ortaya çıkmıştır. Çevre muhasebesi sosyal sorumluluk kavramının bir alt sistemi olup, çevre ile ilgili harcamaların belgelenmesi, raporlanması ve denetlenmesidir (Alagöz ve Yılmaz, 2001: 150). Çevre muhasebesi, çevre ve ekonomi arasındaki etkileşim sonucunda ortaya çıkan olumsuzlukların belirlenmesi ve bu olumsuzlukların parasal değerlerinin tespit edilerek kayıt altına alınması ve takip edilmesidir (Çalış, 2013: 181). Çevre muhasebesi, muhasebenin sosyal sorumluluk ilkesi gereği, işletmelerin doğa üzerindeki zararlarının tespiti sonrasında ortaya çıkan maliyetlerin hesaplanması, sınıflandırılması, izlenmesi ve raporlanması şeklinde ortaya çıkmıştır (Alagöz ve Yılmaz, 2001: 148). Özkol'un (1998: 21) çevre muhasebesi ile ilgili yapılan tanımlamalarının derlemesinden çevre muhasebesinin amaçları şu şekilde sıralanmıştır (Güney ve Can, 2015: 326);

- Geleneksel muhasebe uygulamalarının gelişmesine katkı sağlayan araştırmaların yapılması,

- $\quad$ Çevresel maliyet ve çevre kaynaklı gelirlerin ayrı olarak tanımlanması,

- $\quad$ Isşletmenin iç ve dış paydaşları için performans raporlarının geliştirilmesi,

- Yönetim kararlarında daha fazla çevresel yararlılık elde edebilmek amacıyla yeni finansal ve finansal olmayan muhasebe bilgi ve kontrol sistemlerinin oluşturulması.

Çevre muhasebesi çevreye dolayısıyla topluma karşı olan sosyal sorumluluk bilinci ve ihtiyacı ile başlamaktadır. Çevre muhasebesi özellikle topluma karşı sosyal sorumluluk kavramı gereği ortaya çıkan ya da çıkması olası çevre maliyetleri ile ilgilenmektedir. İşletmelerde oluşan çevresel maliyetleri, çevreyi etkilemeden alınan koruma maliyetleri ve çevre etkilendikten sonra ortaya çıkan olumsuzlukların ortadan kaldırılması için oluşan maliyetler olarak ayırmak mümkündür. Çevre muhasebesi, geleneksel işletme yaklaşımlarından ziyade modern işletme yaklaşımları olarak ortaya çıkmaktadır. Bu nedenle son yıllarda çevre muhasebesi ile ilgili çeşitli çalışmalar yapılmaktadır.

\section{LITTERATÜR ÖZETİ}

Çevre muhasebesi başta işletmeler olmak üzere toplumun bütün kesimini ilgilendirmesi gereken ortak konulardandır. Çevre muhasebesine sadece muhasebe olarak kayıtların ve raporların hazırlanması olarak görmek konuyu sadece teknik boyutuyla incelemekten öteye gidemeyecektir. Özellikle son yarım asırda güncelliğini koruyan çevre ve çevre muhasebesi konularında ortaya çıkan çalışmalardan işletmelerle ilgili olan bazı çalışmalar şu şekildedir;

Coşkun ve Karaca (2008), KOBİ'lerin katlanmak zorunda oldukları çevresel maliyetlerin üretim maliyetleri içindeki yerini metal işleme sektöründe faaliyet gösteren bir KOBI'de araştırmışlardır. Çalışma sonucunda, beş yıllık bir planla uygulanan çevre maliyetlerinin işletmenin toplam maliyetlerinin \%7'si oranında gerçekleşeceği belirlenmiştir.

Lazol vd. (2008) Bursa İlinde KOBİ'ler üzerinde gerçekleştirdiği çalışmada, sürdürülebilir kalkınma, muhasebe ve sosyal sorumluluk kavramları ilişkisi ve çevre 
muhasebesinde çevresel maliyetlerin muhasebeleştirilmesini ele almıştır. Çalışma, işletmelerin özellikle arıtma maliyetleri ve atıkları önlemeye yönelik maliyetlerin arttırılmasının, sürdürülebilir kalkınmanın sağlanmasında ortaya çıkan bilincin arttığ sonucuna ulaşmıştır.

Kırlığlu ve Fidan (2009) Sakarya İlinde gerçekleştirdiği çalışmada, işletmelerin çevre ve atık yönetimi konusundaki faaliyetleri ve bunların arasındaki ilişki ile bunların muhasebeleştirilmeleri incelenmiştir. Çalışma sonucunda işletmelerin çevre politikasına sahip olma konusunda adımlar attıkları ancak bu işletmelerin genellikle orta ve büyük ölçekli işletmeler olduğu ve özellikle ayrı bir atık yönetim birimi olan işletmelerin yine büyük ölçekli işletmeler olduğu tespit edilmiştir. Ayrıca çalışmada personel sayısının işletmelerin çevre ve atık yönetimleri üzerinde etkili olduğu görülmüştür.

Korukoğlu (2011), İzmir ilinde farklı sektörlerde faaliyet gösteren işletmelerde çevre muhasebesinin uygulanışını incelemiş ve anket yöntemi uygulanan çalışmanın sonuçları özetlenmiştir. İşletmelerin çevre muhasebesinin uygulanma şeklinin işletmenin genelinde uygulandığı, işletme çalışanlarının çevreye duyarlılık, ISO 14001, enerji tasarrufu vb. konularda eğitime tabi oldukları sonucuna ulaşmıştır.

Kırlığlu ve Fidan (2011), Sakarya İlindeki araştırmalarında, işletmelerin çevre duyarlılıklarını hem OSB içindeki hem de OSB dışında faaliyet gösteren işletmelerdeki farklılıkları tespit etmeyi amaçlamışlardır. Çalışmada, OSB içindeki ve dışındaki işletmelerin çevresel maliyetleri bakımından bir farklılığın olmadığı ve en fazla maliyetin enerji maliyetlerinin olduğu sonucuna ulaşmışlardır.

Aydın (2012), işletme paydaşlarının çevre muhasebesi uygulamalarına etkilerini ölçmeye yönelik Türkiye ve Birleşik Krallık’ta faaliyet gösteren konaklama işletmelerini karşılaştırmalı incelemiştir. Araştırma sonucunda paydaş gruplarından hissedarlar ve yöneticilerin her iki ülkede de çevre muhasebesi konusunda işletmeler üzerinde etkisinin olduğu ve konaklama işletmelerinde çevresel maliyetlerin ayrı olarak raporlanmasında Türkiye'de toplumun, Birleşik Krallık'ta ise kredi kuruluşlarının etkili olduğu tespit edilmiştir.

Beller vd. (2012), bir çimento fabrikası özelinde çevre yatırım maliyetleri, muhasebe uygulamaları ve finansal tabloların çevre muhasebesi odağındaki durumu incelemişlerdir. Çalışma sonucunda çimento üretim işletmesinin çevre maliyetlerini, azaltma, kullanma ve zarar maliyetleri olarak üçlü bir sınıflandırma yaptığı anlaşılmıştır.

Gönen ve Güven (2014), seramik sektöründe faaliyet gösteren bir işletmenin çevresel maliyetleri gözden geçirilmiş ve işletmenin çevresel maliyetlerinin muhasebe sürecindeki işleyişi incelenmiştir. Çalışmada işletmenin muhasebe kayıtlarına yer verilmesinin ardından sonuç kısmında çevre muhasebesi uygulamalarının gönüllü ve zorunlu olarak arttırılması önerinde ulunmuşlardır.

Korukoğlu (2014), yine İzmir İlinde gerçekleştirdiği başka bir çalışmada ise işletmelerin çevre muhasebesine yaklaşımları analiz edilmiştir. Analiz sonucunda, işletme ile ilgili olan gruplara karşı çevresel sorumlulukların yerine getirilmesinde çevre muhasebesinin 
kullanımı sonucunda kendilerine de katkılar sağladığını ve sağlayacağının farkında vardıkları sonucuna ulaşılmıştır.

Ceyhan ve Ada (2015) Kahramanmaraş ilinde, işletmelerdeki çevreye duyarlılık kavramının önemi üzerine bir çalışma gerçekleştirmişlerdir. Çalışmada, çevreye duyarlı işletmeliğin, yönetim, muhasebe ve finansman, halkla ilişkiler, pazarlama, üretim AR-Ge, insan kaynakları ve bilgi teknolojileri boyutları demografik özellikler ve işletmelerin özellikleri açısından incelenmesi ile işletmelerdeki çevre bilincinin arttığı sonucuna ulaşılmıştır.

Bilen ve Seyitoğulları (2016), Diyarbakır sanayi sektöründe faaliyet gösteren işletmelerin çevresel konulara ve çevre muhasebesini algılarını ölçmeye yönelik çalışmada, şeffaflık-hesapverilebilirlik, sorumluluk-imaj, değerleme-önleme, belgeleme-kayıtlama ve çevresel sorunları önleme maliyetlerine yönelik oluşturulan hipotezlerin tamamı kabul edilmiştir.

Genel olarak literatürde yer alan çevre muhasebesi ile ilgili işletme odağındaki çalışmalarda, bakış açıları, paydaşlar ve işletme fonksiyonları ile bağlantılı olan çalışmalardır. Ancak özellikle çevre sorunlarının arttığ 1 ve devletlerarasında geniş bir protokol ağına sahip konu hakkında yapılan çalışmalar yeterli değildir. Öyle ki çevre ile yakından ilgili olan sektörlerin başında olan mermer sektörü ve çevre muhasebesi konusu literatürde birkaç çalışmadan öteye gidememiştir. Bu sebeple ekonomisinde mermer üretiminin oldukça önemli bir yeri olan Burdur ili Bucak ilçesinde faaliyet gösteren mermer üretim işletmelerinin çevre muhasebesi ile ilgili farkındalıklarının çevre koruma bilinci ile ilgisinin analizi bir sonraki başlıkta yapılmıştır.

\section{ARAŞTIRMA}

\subsection{Araştırmanın Amacı}

Araştırmanın amacı, çevre ile doğrudan etkileşim içerisinde olan mermer işletmelerinin çevre ve çevre muhasebesine karşı olan farkındalıklarının tespit edilmesidir. "Çalışma, mermer işletmelerinin muhasebenin sosyal sorumluluk anlayışı çerçevesinde hem içinde bulunduğu toplumu hem de kendi geleceklerini yakından ilgilendiren çevre muhasebesi konusundaki farkındalıklarının çevre koruma ile ilişkisi nedir” problem cümlesi çerçevesinde şekillenmiştir.

\subsection{Araştırmanın Kapsamı ve Sınırlılıkları}

Araştırma evreni Batı Akdeniz Bölgesi'nde faaliyet gösteren mermer üretim işletmelerinin tamamı olarak belirlenmiştir. Ancak evrenin tamamını ulaşılmasının araştırma teknikleri (evren-örneklem ilişkisi) açısından fazladan kaynak kullanımını gerektireceği düşüncesi ile, Burdur İli Bucak İlçesi'nin evreni temsil ettiği varsayımı altında, Bucak’ta yer alan mermer üretim işletmelerinin tamamı çalışmaya dahil edilmiştir. Bucak sanayi ve ticaret odasından alınan bilgiye göre Bucak'ta 2017 yılı itibariyle toplam 89adet mermer üretim işletmesi bulunmaktadır. $\mathrm{Bu}$ mermer üretim işletmelerinden 11 tanesi ankete katılmak istememişlerdir. 22 adet mermer üretim işletmesi ise faaliyette olarak görünmelerine rağmen beyan ettikleri adreslerde bulunamamıştır. Geri kalan 56 adet mermer üretim işletmesi 
çalışmaya gönüllü olarak dahil olmuşlar ve çalışma hipotezleri bu sayı üzerinden test edilmiştir.

\subsection{Araştırmanın Yöntemi}

Araştırmada amaca anket yöntemi ile ulaşılmaya çalışılmıştır. Anket tanımlayıcı ve işletmelerin bakış açılarını anlamaya yönelik tutumların yer aldığı iki ana bölümden oluşmuştur. İşletmeleri tanımaya yönelik hazırlanan ilk bölümde tanımlayıcı 8 adet çoktan seçmeli soru, ikinci bölümde ise 20adet likert ölçeğine göre hazırlanmış yargı soruları bulunmaktadır.

Anket formunun birinci kısmındaki sorular katılımcı işletmeler hakkında bilgi elde edebilmek amacı ile sadece frekans ve yüzdelik bilgileri verilmiştir. İkinci kısımdaki sorular ise hipotezleri test etmeye yönelik dizayn edilmiştir. Buna göre SPSS 20.0 programı ile analiz edilmiştir.

Çalışmanın ikinci bölümünün güvenilirlik analizi yapılmıştır. Buna göre ölçeğin Cronbach Alpha değeri \% 92 olduğu ortaya çıkmış ve araştırmanın güvenilirliğinin oldukça yüksek olduğu söylenebilmektedir. Araştırmanın ikinci bölümü soruları regresyon analizine tabi tutulmuş ve devam eden kısımdaki hipotezlerin doğruluğu test edilmiştir.

\subsection{Araştırmanın Sayıltı ve Hipotezleri}

Araştırmada Bucak örnekleminde hazırlanan anket sorularının tamamının katılımcılar tarafindan anlaşıldığ 1 ve Bucak ilçesinin mermer üretim işletmelerinin sosyo-ekonomik ve kültürel benzerlikler doğrultusunda Batı Akdeniz Bölgesini temsil edeceği çalışmanın sayıltılarını oluşturmaktadır. Bu sayıltılar doğrultusunda hazırlanan ana hipotezinin "Mermer üretim işletmelerinde çevre muhasebesine olumlu yaklaşımda, sosyal sorumluluk kavramı çevre koruma bilinci ile ilgili olduğu istatistiksel olarak anlamlıdır" olmasının yanında alt hipotezler şu şekildedir;

H1: Mermer üretim işletmelerinde çevre muhasebesinin, işletmelerin kanunlarla karşı karşıya gelmesini önleyerek cezai işlemlere karşı uyardığının farkındalığı, işletmelerin sosyal sorumluluk kapsamında çevre koruma bilinci ile ilgili olduğu istatistiksel olarak anlamlıdır.

H2: Mermer üretim işletmelerinde çevre muhasebesinin, işletmelerin çevresel sorunlarını önleyici yatırımların yapılmasına neden olduğunun farkındalığı, işletmelerin sosyal sorumluluk kapsamında çevre koruma bilinci ile ilgili olduğu istatistiksel olarak anlamlidir.

H3: Mermer üretim işletmelerinde çevre muhasebesi sayesinde başta hammadde ve enerji olmak üzere birçok konuda tasarruf sağladığının farkındalığı, işletmelerin sosyal sorumluluk kapsamında çevre koruma bilinci ile ilgili olduğu istatistiksel olarak anlamlıdır.

H4: Mermer üretim işletmelerinde çevre muhasebesinin kullanılması ile elde edilen sonuçların işletme imajına olumlu katkı sağladığının farkındalığı, işletmelerin sosyal sorumluluk kapsamında çevre koruma bilinci ile ilgili olduğu istatistiksel olarak anlamlıdır. 
H5: Mermer üretim işletmelerinde çevre ile ilgili uygulamaların yer almadığı bir muhasebe sisteminin sosyal sorumluluk açısından eksik kalacağının farkındalığı, işletmelerin sosyal sorumluluk kapsamında çevre koruma bilinci ile ilgili olduğu istatistiksel olarak anlamlidir.

H6: Mermer üretim işletmelerinde çevre muhasebesi çevre-sektör-devlet ilişkisi ile işlerlik kazanabileceğinin farkındalığı, işletmelerin sosyal sorumluluk kapsamında çevre koruma bilinci ile ilgili olduğu istatistiksel olarak anlamlıdır.

H7: Mermer üretim işletmelerinde çevre muhasebesinin bir sistem olduğunun farkındalığı, işletmelerin sosyal sorumluluk kapsamında çevre koruma bilinci ile ilgili olduğu istatistiksel olarak anlamlıdır.

H8: Mermer üretim işletmelerinde çevre muhasebesi uygulamalarının ayrı bir raporlama sistemi ile gösterilmesi gerektiğinin farkındalığı, işletmelerin sosyal sorumluluk kapsamında çevre koruma bilinci ile ilgili olduğu istatistiksel olarak anlamlıdır.

H9: Mermer üretim işletmelerinde çevre muhasebesi çevre ile ilgili konularda yönetime yol gösterici rol oynadığının farkındalığı, işletmelerin sosyal sorumluluk kapsamında çevre koruma bilinci ile ilgili olduğu istatistiksel olarak anlamlıdır.

H10: Mermer üretim işletmelerinde çevre muhasebesinin kullanılması gelecek nesillere daha yeşil bir yaşam bırakılmasına katkı sağlayacağı, işletmelerin sosyal sorumluluk kapsamında çevre koruma bilinci ile ilgili olduğu istatistiksel olarak anlamlıdır.

\subsection{Araştırmanın Bulguları}

Araştırmanın bulguları başlığı altında araştırma sonucunda elde edilen verilerden tanımlayıcı soruların frekans ve yüzde dağılımları ile likert ölçekli soruların regresyon analizi sonucunda elde edilen bulgularına yer verilmiştir.

\subsubsection{Araştırmanın Tanımlayıcı Sorularının Analizi}

Araştırmada elde edilen tanımlayıcı sorulardan işletmelerin faaliyet süreleri çalışan sayıları sahip oldukları sertifikalar ve işletmelerin hukuki yapısı ile ilgili veriler tablo1'de gösterilmiştir.

Tablo 1a'ya göre sırasıyla araştırmaya katılan işletmelerin; 20'si yani \%35,7'si 0-5 yılları arasında, 9 (\%16,1)'i 6-10 yılları arasında, 9'u \%16'sı, 8'i yani \%14,3'ü 16-20 y1lları arasında, işletmelerin 10 adedi $(\% 17,9)$ 'u ise 21 ve daha fazla yıldan fazla faaliyet göstermektedir. Diğer yandan çalışmaya katılan toplam 56 işletmenin 17'si yani \%30,4'ü 1 ile 9 arasında çalışana sahipken, 10'u (\%17,9)'u 10-19 çalışan, 12 (21,4)'si 20-29 çalışan, 3 (\%5,4)’ü 30-39 çalışan, 4'ü yani \%7,1'i 40-49 çalışanla faaliyetlerini sürdürürken 10 işletme yani \%17,9 'u ise 50 ve üzeri çalışan sayısı ile faaliyetlerini sürdürmektedir. 
Tablo 1-a. Katılımcı İşletmelerin Tanımlayıcı Sorularının Frekans Dağılımları

\begin{tabular}{|c|c|c|c|}
\hline Tanımlayıcı Sorular & Seçenekler & Frekans & Yüzde \\
\hline \multirow{6}{*}{ Faaliyet Süresi } & $0-5$ Yil & 20 & 35,7 \\
\hline & 6-10 Yil & 9 & 16,1 \\
\hline & 11-15 Yil & 9 & 16,1 \\
\hline & 16-20 Yil & 8 & 14,3 \\
\hline & 21 ve üzeri & 10 & 17,9 \\
\hline & Toplam & 56 & 100 \\
\hline \multirow{7}{*}{ Çalışan Sayıları } & 1-9 Kişi & 17 & 30,4 \\
\hline & 10-19 Kişi & 10 & 17,9 \\
\hline & 20-29 Kişi & 12 & 21,4 \\
\hline & 30-39 Kişi & 3 & 5,4 \\
\hline & 40-49 Kişi & 4 & 7,1 \\
\hline & 50 ve üzeri & 10 & 17,9 \\
\hline & Toplam & 56 & 100 \\
\hline \multirow{7}{*}{ Sertifikalar } & ISO 18000/18001 & 2 & 3,6 \\
\hline & ISO 14000/14001 & 6 & 7 \\
\hline & ISO 9000/9001 & 16 & 28,6 \\
\hline & Diğer & 12 & 21,4 \\
\hline & Yok & 21 & 37,5 \\
\hline & Yanitlanmayan & 3 & 5,4 \\
\hline & Toplam & 56 & 100 \\
\hline \multirow{4}{*}{ Hukuki Yapı } & Adi Şirket & 11 & 19,6 \\
\hline & Limited Şirket & 38 & 67,9 \\
\hline & Anonim Şirket & 7 & 12,5 \\
\hline & Toplam & 56 & 100 \\
\hline
\end{tabular}

Katılımcı olan 56 işletmenin 2'si (\%3,6) ISO 18000/18001 sertifikası, 2'si (\%3,6) ISO 14000/14001 sertifikası, 16's1 yani \%28,6's1 ISO 9000-9001 sertifikasina sahip olanlardan oluşurken, $12(21,4)$ diğer sertifikalara sahip ve $21 \% 37,5$ sertifikaya sahip olmayan işletmelerdir. Ayrıca 56 işletmenin 3'ü yani \%5,4'ü bu soruya yanıt vermemiştir. Çalışmaya katılan 56 işletmenin 11'i yani $(\% 19,6)$ 'sının adi şirket, 38'ini $(67,9)$ limited şirket ve 7 'sini yani \%12,5'ini anonim şirket hukuki yapıya sahiptir.

Tablo 1b'de işletmelerin çevre ile ilgili sorumlu hissedilen çevre sorunları, ceza alınıp alınmaması, çevre muhasebesi ve çevresel maliyetlerin raporlanmasının zorunlu olması ve çevre muhasebesinin zorunlu olması durumunda ortaya çıkacak yeniliklere muhasebecilerinin yeniliklere cevap verip veremeyeceğine yönelik tanımlayıcı soruları yer almaktadır. $\mathrm{Bu}$ tablonun ilk sorusu olan işletmelerinin hangi çevre konularında sorumlu hissettiklerine yöneliktir. $\mathrm{Bu}$ soruda katılımcı işletmelerin birden fazla seçenek işaretlemelerine müsaade edilmiştir. İşletme katılımcıları toplamda 97 frekansla yanıtladıkları sorunların yer aldığı soruda gürültü kirliliğine 21 frekansla (\%22) en yüksek sorumluluk konusunu belirtmişlerdir. İkinci en yüksek sorumluluk hissedilen konu ise, görüntü kirliliği (\%19)'luk payla 18 frekans yer almıştır. İşletmelerin en az sorumlu gördükleri çevre sorunu ise 3 frekansla radyoaktif kirlilik olmuştur. Mermer işletmelerin çevre ile birebir ilişkili oldukları düşünüldüğünde çevre ile ilgili herhangi bir konuda ceza alıp almadıkları sorusu yöneltildiğinde sadece 1 işletme ceza aldığını, 1 işletme hatırlamadığını ve 54 işletme ise ceza almadığını ifade etmiştir. 
Tablo 1-b. Katılımcı İşletmelerin Tanımlayıcı Sorularının Frekans Dağılımları

\begin{tabular}{|c|c|c|c|}
\hline Tanımlayıcı İfadeler & Seçenekler & Frekans & Yüzde \\
\hline \multirow{9}{*}{$\begin{array}{l}\text { Sorumlu Hissedilen Çevre } \\
\text { Sorunları (Birden fazla seçenek } \\
\text { işaretlenmiştir) }\end{array}$} & Hava Kirliliği & 12 & 12 \\
\hline & Su Kirliliğgi & 9 & 0,09 \\
\hline & Radyoaktif Kirlilik & 3 & 0,03 \\
\hline & Toprak Kirliliği & 13 & 0,13 \\
\hline & Gürülttü Kirliliği & 21 & 0,22 \\
\hline & Görüntü Kirliliğ̆i & 18 & 0,19 \\
\hline & Diğer & 4 & 0,04 \\
\hline & Hiçbiri & 17 & 0,17 \\
\hline & Toplam & 97 & 100 \\
\hline \multirow{4}{*}{ Cezai İşlemler } & Evet & 1 & 1,8 \\
\hline & Hayır & 54 & 96,4 \\
\hline & Hatırlanmıyor & 1 & 1,8 \\
\hline & Toplam & 56 & 56 \\
\hline \multirow{4}{*}{$\begin{array}{l}\text { Çevre Muhasebesi ve Çevresel } \\
\text { Maliyetlerin Raporlanmasının } \\
\text { Yasal Hale Gelmesi }\end{array}$} & Evet & 39 & 69,6 \\
\hline & Hayır & 8 & 14,3 \\
\hline & Fikrim yok & 9 & 16,1 \\
\hline & Toplam & 56 & 100 \\
\hline \multirow{4}{*}{$\begin{array}{l}\text { Çevre Muhasebesinin zorunlu } \\
\text { olması durumunda } \\
\text { muhasebecinin bu işi } \\
\text { yapabilmesi }\end{array}$} & Evet & 36 & 63,4 \\
\hline & Hayır & 9 & 16,1 \\
\hline & Fikrim yok & 11 & 19,6 \\
\hline & Toplam & 56 & 100 \\
\hline
\end{tabular}

Çevre muhasebesi ve çevresel maliyetlerin raporlanmasının yasal hale gelmesinin istenip istenmediğine yönelik sorulan soruda, katılımcı işletmelerin 39'u $(\% 69,6)$ olumlu, 8'i $(\% 14,3)$ olumsuz yanıt verirken, 9'u $(\% 16,1)$ bu konuda fikrinin olmadığını beyan etmiştir. Tanımlayıcı soruların son sorusu olarak çevre muhasebesinin zorunlu olması durumunda muhasebecilerinin işin gereklerine göre hareket edip edemeyeceği sorulmuş ve 36 katılımcı $(\% 63,4)$ muhasebecilerinin yapabileceğini, 9'u $(\% 16,1)$ muhasebecilerinin çevre muhasebesine uyum sağlayamayacağını ve 11 'i $(\% 19,6)$ ise bilmediğini ifade etmiştir.

\subsubsection{Fonksiyonel Değişkenlere İliş̧kin Bulgular}

Mermer üretim işletmelerinin sosyal sorumluluk kavramı çerçevesinde çevre koruma bilincinin çevre muhasebesi ile ilişkilendirilmesi ve bu ilişkinin varlığı söz konusu olduğunda yönünün ne olduğunu tespit etmeye yönelik hazırlanan sorular regresyon analizi ile test edilerek elde edilen sonuçlarla hipotezlerin red veya kabul testi gerçekleştirilmiştir. Çalışmanın ilk hipotezinin test edildiği tablo aşağıda gösterilmiştir.

Tablo 2. Çevre Koruma Bilinci ve Çevre Muhasebesinin Cezai İşlemleri Önlemesi

\begin{tabular}{|c|c|c|c|c|c|}
\hline & R Square & Durbin-Watson & VIF & B & Sig. \\
\hline & 0,298 & 2,121 & 1,000 & 0,693 & \multirow{3}{*}{0,000} \\
\hline \multirow[b]{2}{*}{ Regresion } & & & & $\mathbf{F}$ & \\
\hline & & & & 22,952 & \\
\hline
\end{tabular}


Tablo 2'de H1 hipotezi kapsamında yapılan analiz sonucunda F=22,952; sig $=0,000 \leq 0,05$ olduğu için model bir bütün olarak istatistiksel olarak anlamlıdır. Modelin $\mathrm{R}^{2}$ değeri 0,298'tir. Buna göre katılımcıların çevreye duyarlılıkları ve çevre bilincindeki değişmenin \%29,8'lik kısmı, çevre muhasebesinin cezai işlemlere karşı uyarma hususunda ki değişmeler tarafından açıklanmaktadır (Kalaycı:2009). Ayrıca 2,121 D.W. testi değeri modelde otokoreslasyon olmadığını göstermektedir (Kalayc1:2009). Yapılan analiz sonucunda katılımcıların çevre bilincinin 1 birimlik artışında, çevre muhasebesinin işletmecileri cezai işlemlere karşı uyarmasının kabulünü 0,693 birim artırır ve VIF=1,000'lık değer bağımsız değişkenler arasında çoklu bağlantı olduğunu gösterir.

Tablo 3. Çevre Koruma Bilinci ve Çevre Muhasebesinin Çevresel Sorunları Önleyici Yatırımların Yapılmasına Neden Olması

\begin{tabular}{|c|c|c|c|c|c|}
\hline & R Square & Durbin-Watson & VIF & B & Sig. \\
\hline & 0,144 & 2,049 & 1,000 & 0,469 & \multirow[b]{2}{*}{0,004} \\
\hline Regi & & & & $\begin{array}{c}\mathbf{F} \\
9,085\end{array}$ & \\
\hline
\end{tabular}

Tablo 3'te oluşturulan model; $\mathrm{F}=9,085$; sig=0,004, 0,05 anlaml1lık düzeyince bir bütün olarak her düzeyde anlamlıdır ve işletmecilerin çevre duyarlılıklarındaki değişmenin, \%14,4'lik kısmı, çevre muhasebesinin çevre sorunlarını önleyici yatırımların yapılması üzerindeki etkisinin kabulündeki değişmeler tarafından açıklanmaktadır. Yapılan test sonucunda katılımcıların çevre duyarlılıklarında ki 1 birimlik artışın, çevre sorunlarının önleyici yatırımların yapılmasını 0,469 birim artırmaktadır ve Durbin Watson= 2,049 değeri modelde otokoreslasyon olmadığını göstermekte ayrıca 1,000'lık VIF değeri bağımsız değişkenler arasında çoklu bağlantı olduğunu göstermektedir.

Tablo 4. Çevre Bilinci ve Çevre Muhasebesinin Başta Hammadde ve Enerji Olmak Üzere İşletme Kaynaklarında Tasarrufa Neden Olması

\begin{tabular}{|c|c|c|c|c|c|}
\hline & R Square & Durbin-Watson & VIF & B & Sig. \\
\cline { 2 - 5 } & 0,096 & 2,737 & 1,000 & 0,458 & \multirow{2}{*}{0,020} \\
\cline { 2 - 3 } \multirow{2}{*}{ Regresion } & \multicolumn{3}{|l}{} & F & 5,753 \\
\hline
\end{tabular}

H3 hipotezi kapsamında mermer işletmelerine yöneltilen anketlerin analizleri sonucunda oluşturulan model 0,05 anlamlılık düzeyinde bir bütün olarak anlamlıdır. $\mathrm{R}^{2}=0,096$ değeri çevre bilincindeki değişmenin \%9,6'lık kısmı çevre muhasebesi sayesinde işletmelerin başta hammadde ve enerji olmak üzere birçok konuda tasarruf sağlamasındaki değişmeler tarafindan açıklanmaktadır. D.W testi sonucunda yukarıdaki tabloda modelde otokorelasyon olduğu görülmektedir. D.W katsayısı 1,5-2,5 aralığına yakın olduğu için analize devam edilmiştir. Regresyon analizi sonucunda çevre bilincindeki 1 birimlik artış, işletmelerin çevre muhasebesi sayesinde tasarruf yapmalarını 0,458 birim artırır. Ayrıca modelde bağımsız değişkenler arasında çoklu bağlantı olduğu görülmektedir. 
Tablo 5.Çevre Bilinci ve Çevre Muhasebesinin İşletmenin İmajına Katkı Sağlaması

\begin{tabular}{|c|c|c|c|c|c|}
\hline & R Square & Durbin-Watson & VIF & $\mathbf{B}$ & Sig. \\
\hline & 0,334 & 1,424 & 1,000 & 0,836 & \multirow[b]{2}{*}{0,000} \\
\hline Regresion & & & & $\frac{\mathbf{F}}{27120}$ & \\
\hline
\end{tabular}

Tablo 5'de oluşturulan modelin $\mathrm{F}=27,120$; sig $=0,000 \leq 0,05$ değeri 0,05 anlamlıl1k düzeyince bir bütün olarak anlamlı olduğu ve VIF değerinin 1,000 olması sonucunda, bağımsız değişkenler arasında çoklu bağlantı olduğu görülmektedir. Ayrıca genellikle 1,5-2,5 civarındaki Durbin-Watson testi otokorelasyon olmadığını göstermekte ancak yapılan test sonucunda D.W katsayının bu koşulu sağlamadığı için modelde otokorelasyon sorunu olduğu görülür ancak değerler 1,5-2,5 aralığına yakın olduğu için analize devam edilmiştir (Kalaycı: 2009). Modelin $\mathrm{R}^{2}$ değeri 0,334 olup, katılımcıların çevre bilincindeki değişmesinin \%33,4'lük kısmı, çevre muhasebesinin işletme imajına katkısı üzerindeki değişmeler tarafından açıklanmaktadır. Oluşturulan modelde işletmelerin çevre bilinci ve duyarlılıklarındaki 1 birimlik artış, çevre muhasebesinin işletme imajını artması üzerinde 0,836 birimlik artı̧s söz konudur.

Tablo 6. Çevre Bilinci ve Çevre İle İlgili Uygulamaların Yer Almadığı Bir Muhasebe Sisteminin Sosyal Sorumluluk Kavramı Açısından Eksikliği

\begin{tabular}{|l|c|c|c|c|c|}
\hline & R Square & Durbin-Watson & VIF & B & Sig. \\
\cline { 2 - 5 } & 0,139 & 1,723 & 1,000 & 0,595 & \multirow{2}{*}{0,005} \\
\cline { 1 - 2 } Regresion & \multicolumn{3}{|l}{} & $\mathbf{F}$ & 8,723 \\
\end{tabular}

Tablo 6'de yapılan analiz sonucunda H5 hipotezini test etmek amaciyla hazırlanan soruların regresyon testi sonucunda model 0,05 anlamlılık düzeyinde bir bütün olarak her düzeyde anlamlı olup WIF=1,000 olduğu için bağımsız değişkenler arasında çoklu bağlantı vardır. Durbin-Watson katsayısının 1,5-2,5 düzeyinde oluşturulan modelde otokorelasyon olmadığı görülmektedir. Katılımcıların çevreye karşı duyarlılıklarındaki değişmenin \%13,9'luk kısmı, çevre muhasebesinin eksikliğinin sosyal sorumluluk kavramı açısından eksikliğinde değişmeler tarafından açıklanmakta olup, çevre duyarlılığındaki 1 birimlik artış, çevre muhasebesinin eksikliğinin muhasebe sisteminin sosyal sorumluluk kavramının eksikliğini 0,595 birim artırmaktadır.

Tablo 7. Çevre Bilinci ve Çevre Muhasebesinin İşletme-Sektör-Devlet İlişkisi İle İşlerlik Kazanması

\begin{tabular}{|c|c|c|c|c|c|}
\hline & R Square & Durbin-Watson & VIF & B & Sig. \\
\hline & 0,290 & 1,509 & 1,000 & 0,687 & \multirow[b]{2}{*}{0,000} \\
\hline Regresion & & & & $\frac{\mathbf{F}}{22072}$ & \\
\hline
\end{tabular}

Yapılan anket çalışmasında H6 kapsamında hazırlanan soruların regresyon testi sonucunda sig $=0,000 \leq 0,05$ olduğu için model bir bütün olarak istatistiksel açıdan oldukça anlamlıdır. Yukarıdaki tabloda, modelde 1,000'lık VIF değeri bağımsız değişkenler arasında çoklu bağlantı olduğunu ve 1,509'luk Durbin-Watson değeri otokorelasyon olmadığ 
görülmektedir. $\mathrm{R}^{2}=0,290$ olması çevre bilincindeki değişmenin \%29'luk kısmı, çevre muhasebesi uygulamalarının, işletme-sektör-devlet ilişkisinin işlerlik kazanacağındaki değişmeler tarafindan açıklanmaktadır. Ayrıca çevre bilincindeki 1 birimlik artış, işletmesektör-devlet ilişsisindeki işlerliği 0,687 birim artırmaktadır.

Tablo 8: Çevre Bilinci ve Çevre Muhasebesinin Bir Sistem Olarak Algılanması

\begin{tabular}{|c|c|c|c|c|c|}
\hline & R Square & Durbin-Watson & VIF & B & Sig. \\
\cline { 2 - 5 } & 0,210 & 1,653 & 1,000 & 0,584 & 0,000 \\
\cline { 2 - 4 } Regresion & \multicolumn{3}{|c}{} & F & 14,322 \\
\hline
\end{tabular}

Tablo 8'de F=14,322; sig=0,000 $\leq 0,05$ olduğu için oluşturulan model 0,05 anlaml111k düzeyinde, bir bütün olarak istatistiksel açıdan anlamlıdır. Ayrıca VIF=1,000 değeri modelin bağımsız değişkenler arasında çoklu bağlantı olduğunu gösterir. Tabloda Durbin-Watson test sonucunda $(\mathrm{DW}=1,653)$ modelde otokorelasyon olmadığı ortaya çıkmaktadır. Modelin $\mathrm{R}^{2}$ değeri 0,210'dur. Buna göre katılımcıların çevreye duyarlılıkları ve çevre bilincindeki değişmenin \%21'lik kısmı, çevre muhasebesinin çevre bilincinin artırmasındaki bakış açısındaki değişmeler tarafından açıklanmaktadır. Yapılan analiz sonucunda katılımcıların çevre bilincinin 1 birimlik artışında çevre muhasebesinin çevre bilincinin artırması 0,584 olmaktadir.

Tablo 9. Çevre Bilinci ve Çevre Muhasebesi Uygulamalarının Ayrı Raporlanması

\begin{tabular}{|c|c|c|c|c|c|}
\hline & R Square & Durbin-Watson & VIF & B & Sig. \\
\cline { 2 - 5 } & 0,239 & 1,863 & 1,000 & 0,658 & \multirow{2}{*}{0,000} \\
\cline { 2 - 4 } Regresion & \multicolumn{3}{|c}{} & 16,935 & \\
\hline
\end{tabular}

H8 hipotezini destekleyen sorulara yapilan test sonucunda model 0,05 anlamlilık düzeyince bir bütün olarak her düzeyde istatistiksel olarak anlamlıdır. Modelde otokorelasyon yoktur ve 1,000'lık VIF değerinde bağımsız değişkenler arasında çoklu bağlantı söz konudur. Analiz sonucunda bulunan $\mathrm{R}^{2}$ değeri 0,239 'tur. $\mathrm{Bu}$ durumda çevreye karşı duyarlılıktaki değişmenin \%23,9'luk kısmı çevre muhasebesinin ayrı bir raporlama sistemi ile gösterilmesindeki değişmeler tarafından açıklanmaktadır. Ayrıca çevreye karşı duyarlılıkta ki 1 birimlik artış, çevre muhasebesinin ayrı bir raporlama sistemi ile gösterilmesini 0,658 birim artırmaktadir.

Tablo 10. Çevre Bilinci ve Çevre Muhasebesinin Çevre İle İlgili Konularda Yönetime Yol Göstermesi

\begin{tabular}{|c|c|c|c|c|c|}
\hline & R Square & Durbin-Watson & VIF & B & Sig. \\
\cline { 2 - 5 } & 0,253 & 1,903 & 1,000 & 0,527 & 0,000 \\
\cline { 2 - 5 } Regresion & \multicolumn{3}{|c}{} & $\mathbf{F}$ & 18,284 \\
\hline
\end{tabular}

Tablo 10'da H9 hipotezini test etmek amacıyla yapılan analiz sonucunda modelin 0,05 anlamlılık düzeyince bir bütün olarak istatistiksel açıdan anlamlı olduğu görülmektedir. Durbin-Watson testi sonucunda D.W değerinin 1,5-2,5 civarında olmasından dolayı modelde otokorelasyon yoktur ve bağımsız değişkenler arasında çoklu bağlantı olduğu görülmektedir. İşletmelerin vermiş oldukları cevaplar doğrultusunda çevre bilincinin 1 birimlik artışında 
çevre muhasebesinin çevre ile ilgili uygulamalarda yönetime yol gösterici nitelikte olması 0,527 arttırmakta ve $\mathrm{R}^{2}$ değerince çevre bilincindeki değişimin \%25,3'lük kısmı, çevre muhasebenin çevre ile ilgili konularda yönetime yol gösterici nitelikte olmasındaki değişmeler tarafından açıklanmaktadır. Kısaca modelin açıklama gücü \%25,'tür.

Tablo 11. Çevre Bilinci ve Çevre Muhasebesinin Kullanımı Gelecek Nesillere Daha Yeşil Bir Yaşam Bırakması

\begin{tabular}{|c|c|c|c|c|c|}
\hline & R Square & Durbin-Watson & VIF & B. & Sig. \\
\hline & 0,463 & 2,296 & 1,000 & 0,830 & \multirow{3}{*}{0,000} \\
\hline \multirow{2}{*}{ Regresion } & & & & $\mathbf{F}$ & \\
\hline & & & & 46,505 & \\
\hline
\end{tabular}

Oluşturulan son modelin Tablo 11'deki $\mathrm{F}=46,505$; sig=0,000 değeri modelin 0,005 anlamlılık düzeyinde bir bütün olarak istatistiksel olarak oldukça anlamlı olduğunu göstermektedir. Ayrıca modelde otokorelasyon yok ancak bağımsız değişkenler arasında çoklu bağlantı vardır. Tabloda çevre bilincindeki değişimin \%46,3'ünün modele dahil ettiğimiz çevre muhasebesinin kullanılmasının gelecek nesillere daha yeşil bir yaşam bırakılmasındaki unsur olmasındaki değişkeni tarafından açıklanmaktadır. Yani modelimizin açıklama gücü \%46,3'tür. Oluşturulan modelde çevreye duyarlılıktaki 1 birimlik artış, çevre muhasebesinin gelecek nesillere daha yeşil bir yaşam bırakmasına imkân olmasını 0,830 artırmaktadir.

\section{SONUÇ}

Sosyal sorumluluk kavramı kapsamında çevreyi koruma (önleme) amaçlı yapılan yatırımlar günümüzde işletmelerin maliyetlerini arttıran somut maliyetlerdir. Bazı maliyetler yasalarla zorunlu hale getirilmiş iken bazı maliyetler hala zorunlu hale gelmemiştir. İşletmelerin özellikle, doğal kaynakları tüketme kaynaklı maliyetleri henüz doğrudan maliyetler olarak değerlendirilmemektedir.

İşletmenin çevresi ile ortaya çıkan maliyetlerin tamamı çevre muhasebesini ilgilendirmektedir. Ancak yeteri kadar yasal düzenlemelerin olmaması çevre muhasebesi hakkında işletmelerin farkındalıklarının olup olmadığının araştırılması ve farkındalığı bulunmakta ise ne kadarının çevre koruma bilinci ile ilgili olduğu belirlenmesi gerekmiştir. Özellikle mermer üretim işletmeleri gibi ilk madde malzemesini doğadan karşılayan sektör işletmelerinin çevre muhasebesi farkındalığı araştırılmıştır. Çalışma sonucunda kurulan hipotezlerin tamamı kabul edilmiştir. Burdur İli Bucak ilçesi mermer üretim işletmelerinin Batı Akdeniz Bölgesini temsil yeteneği ile elde edilmiştir. Sonuçlara göre, mermer üretim işletmeleri, çevre muhasebesinin işletmeleri kanunlara karşı karşıya gelmesinin önleyeceğinin, çevresel sorunları önleyici yatırımlara neden olacağının, işletmelere başta hammadde ve enerji olmak üzere birçok konuda tasarruf sağlayacağının farkına varmışlardır. Ayrıca mermer üretim işletmeleri, işletme imajına olumlu katkı sağlayacağının farkındadırlar. Bunun yanında işletmeler çevre ile ilgili uygulamaların yer almadığı bir muhasebe sisteminin sosyal sorumluluk kavramı açısından eksik olacağının, çevre muhasebesi uygulamalarının işletme-sektör-devlet ilişkisi ile işlerlik kazanacağının ve çevre muhasebesinin bir sistem olarak algılanması sonucunda çevre bilincini arttıran nedenlerden biri olduğuna katılmaktadırlar. Son olarak çalışma sonucunda çevre muhasebesinin çevre ile ilgili konularda yönetime yol gösterici rol oynadığının, çevre muhasebesi uygulamalarının ayrı bir raporlama 
sistemiyle gösterilmesinin ve çevre muhasebesinin gelecek nesillere daha yeşil bir yaşam bırakılmasına neden olacağının farkındadırlar. Mermer üretim işletmelerinin bu farkındalıklarının oluşmasında çevre koruma bilincinin bulunduğu yine çalışmada ortaya çıkmıştır.

Bundan sonraki çevre muhasebesi ile ilgili çalışmalarda, mermer üretim işletmelerinin farklı bir bölgede uygulanması sonucunda ortaya çıkan sonuçlar araştırılabileceği gibi, elde edilen sonuçların farklı olması durumunda nedenleri de araştırma konusu olabilecektir.

\section{KAYNAKLAR}

Alagöz A.- Yılmaz B., (2001). “Çevre Muhasebesi ve Çevresel Maliyetler”, Selçuk Üniversitesi İİB Sosyal ve Ekonomik Araştırmalar Dergisi, S. 1(2), ss.147-158.

Aydın S., (2012). "Paydaşların Çevre Muhasebesi Konularına Etkileri”, Muhasebe ve Denetime Bakış, 12(36), ss.91-108.

Beller, B.- Deran A. Hatipoğlu A.G. (2012). "Çevre Maliyetlerinin Hesaplanması ve Muhasebeleştirilmesi: Bir Çimento Fabrikasında Vaka Çalışması”, Çağ Üniversitesi Sosyal Bilimler Dergisi, 9(1),ss. 95-121.

Bilen, A.- Seyitoğlu O., (2016). "İş Örgütlerinde Çevre Muhasebesi Algısına Yönelik Bir Araştırma: Diyarbakır İli Örneği”, İnsan ve Toplum Bilimleri Araştırmaları Dergisi, 5(7), ss.1743-1756.

Ceyhan S.- Serkan A., (2015). "İşletme Fonksiyonları Açısından Çevreye Duyarlı İşletmecilik”, Uluslararası Yönetim İktisat ve İşletme Dergisi, 11(26), ss. 115-137.

Coşkun A.- Karaca N., (2008). "KOBI'lerde Çevresel Maliyetlerin Sınıflandırılmasına Yönelik Bir Öneri: Metal İşleme Sektöründen Bir Uygulama”, Ekoloji, 18(69), ss. 5965.

Çalış, Y. E., (2013). “Çevresel Maliyetlerin Muhasebeleştirilmesi”, Marmara Üniversitesi İktisadi ve İdari Bilimler Dergisi, XXXIV, (I), ss.175-190.

Güney C.- Can A. V., (2015). “Çevre Muhasebesi ve Bilgi Teknolojileri”, The Journal of Academic Social Science, 3(6), ss. 323-332.

Gönen S., Güven Z., “Çevresel Maliyetlerin Muhasebeleştirilmesine Yönelik Bir Seramik Fabrikasında Uygulama”, Muhasebe ve Finansman Dergisi, 63, ss.39-58.

Kalaycı Ş.- (2009). SPSS Uygulamalı Çok Değişkenli İstatistik Teknikleri, Asil Yayın Dağıtım Ltd. Şti., Ankara, 4. Bask1.

Keleş, R., (2004). Çevrebilim, İmge Kitabevi, Ankara, 4. Baskı.

Kırlığlu H.- Fidan M. E., (2009). “Atık Yönetimi ve Muhasebesi: Sakarya'daki İşletmeler Üzerinde Bir Araştırma”, Akademik İncelemeler, 4(2), ss.13-36. 
Kırlıŏglu H.- Fidan M. E. (2011), “İşletmelerde Çevresel Maliyetler ve Bir Uygulama”, Akademik Yaklaşımlar Dergisi, 2(1), ss.1-24.

Korukoğlu, A. (2011). “İşletmelerde Çevre Muhasebesi: İzmir İli Uygulaması”, Ege Akademik Bakış, 11 (1), 81-89.

Korukoğlu A., (2014). “İşletmelerin Çevre Muhasebesi Konularına Yaklaşımlarının Analizi”, Ege Akademik Bakış, 14 (3), 481-491.

Lazol İ.- Muğal E.- Yener Y., (2008). “Sürdürülebilir Bir Çevre Muhasebesi ve KOBİ'lere Yönelik Bir Araştırma”, Muhasebe ve Finansman Dergisi, 38, ss.56-69.

Marşap, B.,, (1999). "Kamu Çıkarlarının Korunmasında Muhasebecinin Mesleki Sorumluluğu ve $\mathrm{Bu}$ Sorumluluğun Yerine Getirilmesinde Sinırlayıc1 Faktörler”, Muhasebe Bilim Dünyası Dergisi, 1(1).

Özkol, E. (1998). “Çevre Muhasebesi”, Dokuz Eylül Üniversitesi İ̈BF Dergisi, 13, (1), 15-26. 
